\title{
Prospective scenarios for water quality and ecological status in Lake Sete Cidades (Portugal): The integration of mathematical modelling in decision processes
}

\author{
G. Martins ${ }^{a}$, D.C. Ribeiro ${ }^{a}$, D. Pacheco ${ }^{b}$, J.V. Cruz $^{c, 1}$, R. Cunha ${ }^{\mathrm{d}}$, V. Gonçalves ${ }^{\mathrm{e}}$, R. Nogueira ${ }^{\mathrm{a}}$, \\ A.G. Brito ${ }^{\mathrm{a}, *}$ \\ ${ }^{a}$ IBB - Institute for Biotechnology and Bioengineering, Centre of Biological Engineering, University of Minho, Campus de Gualtar, $4710-057$ Braga, Portugal \\ ${ }^{\mathrm{b}}$ Regional Department of Land Planning and Water Resources, Av. Antero de Quental, 9500-160 Ponta Delgada, Portugal \\ ${ }^{\mathrm{c}}$ CVARG - Geosciences Department, University of Azores, R. Mãe de Deus, 9500-321 Ponta Delgada, Portugal \\ ${ }^{\mathrm{d}}$ CIBIO, Azores Sector, Research Center in Biodiversity and Genetic Resources and Department of Biology, University of Azores, R. Mãe de Deus, \\ 9500-321 Ponta Delgada, Portugal \\ e Department of Biology, University of Azores, R. Mãe de Deus, 9500-321 Ponta Delgada, Portugal
}

\section{A R T I C L E I N F O}

\section{Article history:}

Received 19 June 2007

Accepted 2 March 2008

Available online 18 March 2008

Editorial handling by A. Danielsson

\begin{abstract}
A B S T R A C T
The design of alternative strategies for water and ecological quality protection at the Lake Verde of Sete Cidades should be coupled with the assessment of future trophic states. Therefore, a mathematical model was developed to make prospective scenarios to reduce the risk of environmental degradation of the lake, and a modified Psenner scheme was used to characterize $\mathrm{P}$ distribution in the sediments. The model was able to describe thermal stratification, nutrient cycling $\left(\mathrm{P}, \mathrm{NH}_{4}\right.$ and $\left.\mathrm{NO}_{3}\right)$, dissolved $\mathrm{O}_{2}$, and phytoplankton dynamics in the water column and adjacent sediment layers. Internal $P$ recycling, resulting from thermal stratification and sediment anoxia, was identified as the main cause for the increase of $\mathrm{P}$ concentration in the hypolimnion followed by slow transfer to the epilimnion (about $20 \mu \mathrm{g} / \mathrm{L}$ annual average). Cyanobacteria blooms during spring were explained by the availability of $\mathrm{P}$ and increased water temperature verified during this season. The most sensitive model parameter was sediment porosity. This parameter has a direct effect in dissolved $\mathrm{O}_{2}$ and $\mathrm{P}$ profiles and also in phytoplankton biomass. Finally, different water quality restoration scenarios were identified and their effectiveness assessed. Without the adoption of remediation measures (scenario control), Lake Verde water quality would deteriorate with annual average concentrations of total $\mathrm{P}$ and phytoplankton biomass (dry matter) reaching $34 \mu \mathrm{g} / \mathrm{L}$ and $2 \mathrm{mg} / \mathrm{L}$, respectively, after 10 years of simulation. The reduction of P loads (scenario $P O R A L$ ) into the lake would improve water quality comparatively to the scenario control, reducing the annual average concentrations of total P from $34 \mu \mathrm{g} / \mathrm{L}$ to $26 \mu \mathrm{g} / \mathrm{L}$ and of phytoplankton from $2 \mathrm{mg} / \mathrm{L}$ down to $1.4 \mathrm{mg} / \mathrm{L}$ after 10 years of simulation. In scenario sediments, corresponding to a decrease in the organic content of the sediments, a reduction in the concentrations of total $\mathrm{P}$ and phytoplankton is expected in the first two years of simulation, but this effect, would be attenuated throughout the years due to organic matter sedimentation. The best strategy is obtained by combining external and internal measures for P remediation. Finally, it is recommended that the model be used to integrate the results of water quality monitoring and watershed management plans.
\end{abstract}

(c) 2008 Elsevier Ltd. All rights reserved.

\footnotetext{
* Corresponding author. Tel.: +351253 604400; fax: +351253678986.

E-mail address: agbrito@deb.uminho.pt (A.G. Brito).

${ }^{1}$ Present address: Regional Department of Land Planning and Water Resources, Av. Antero de Quental, 9500-160 Ponta Delgada, Portugal.
} 


\section{Introduction}

Eutrophication of surface water bodies results mainly from anthropogenic activities occurring in their watersheds and constitutes one of the most serious water quality problems, with repercussions on lake chemical and biological characteristics. Nutrient loads from intensive fertilization and livestock manure are difficult to control and have increased in recent times. This human environmental disturbance has become a major problem, particularly during intense precipitation due to the transport of nutrients through the watershed lotic system and ultimately into downstream water bodies. As a result of increased nutrient availability, increased phytoplankton and cyanobacteria can form blooms, causing the release of cyanotoxins, and thus affect multiple water uses. Another measure of eutrophication is the content of $\mathrm{P}$ in lake sediments. Indeed, when the external nutrient sources are controlled, the sediments can act as a source of P and such mobility along the sediment/water column interface is a well known problem for remediation success (Zhou et al., 2001).

Water quality conditions of Lake Verde in the Azores islands (Portugal) are influenced by local agricultural watershed activities. Algae blooms and the release of $\mathrm{P}$ from the sediments during the summer are recurrent events in the lake (Santos et al., 2004; Medeiros et al., 2004). In order to reduce the external input of nutrients, the Regional Government has designated eight Azorean lake watersheds as "vulnerable areas" complying with Nitrates Directive 91/ 676/EEC and a watershed management plan for the Lake Verde was approved in 2005.

Biological processes in aquatic ecosystems are complex. The application of mathematical modelling is necessary in order to design management strategies, test functional hypotheses and simulate future states for the system in response to environmental alteration. Several models have been developed in past years for the modelling of different restoration measures in lake ecosystems. For example, PAMOLARE I, a structurally dynamic model based on the UNEP software (Jørgensen et al., 2003), was developed for examining the effects of an ongoing restoration project in Lake Fure by testing different prognosis scenarios (Gurkan et al., 2006). Possible management strategies to improve water quality in an eutrophic water supply reservoir in Argentina were also evaluated using the one-dimensional coupled hydrodynamics and water quality model DYRESM-CAEDYM (Antenucci et al., 2003). Burger et al. (2007) also used DYRESM-CAEDYM to model the relative importance of internal and external nutrient loads on water column nutrient concentrations and phytoplankton biomass. AQUASIM, a computer program designed for the analysis of aquatic systems (Reichert, 1994), was used by Omlin et al. (2001a,b) to model Lake Zürich, and by Frisk et al. (1999) to assess the effect of nutrient loading and water level regulation of water quality in Lake Võrtsjärv. AQUASIM has also been used to model wastewater treatment systems (Nogueira et al., 2005) and soil contamination (Vera et al., 2006). AQUAISM is a reasonable compromise between model simplicity and fundamental process description, basically due to the open structure of biogeochemical processes description that allow modifications and the integration of new processes. Furthermore, the required core experimental data can be easily collected.

The design of alternative strategies for water and ecological quality protection at Lake Verde should be coupled with the assessment of future trophic states. Therefore, the goal of this research was to evaluate the response of the Lake Verde ecosystem to different environmental protection measures.

\section{Materials and methods}

\subsection{Study site}

Lake Sete Cidades is located in the Western part of São Miguel Island, in the archipelago of Azores (Portugal). The lake occurs inside a volcanic crater and has an area of $4.5 \mathrm{~km}^{2}$ representing $23 \%$ of the watershed basin and is divided into two interconnected sub-units: Lagoa Azul (Lake Azul) and Lagoa Verde (Lake Verde). Lake Azul is the largest one, with a surface of approximately $3.6 \mathrm{~km}^{2}$, a water volume of $40 \times 10^{6} \mathrm{~m}^{3}$ and a maximum depth of $24 \mathrm{~m}$. Lake Verde has an extension of $0.9 \mathrm{~km}^{2}$ and a volume of $8 \times 10^{6} \mathrm{~m}^{3}$, with a maximum depth of $21 \mathrm{~m}$. The drainage basin is $13.7 \mathrm{~km}^{2}$ and is composed of permanent grasslands $\left(4.6 \mathrm{~km}^{2}\right)$, forest $\left(8.3 \mathrm{~km}^{2}\right)$, agricultural zones $\left(0.4 \mathrm{~km}^{2}\right)$ and urban areas $\left(0.3 \mathrm{~km}^{2}\right)$ (Santos et al., 2004). This work will focus on Lake Verde because of its eutrophic condition. Indeed, whereas Lake Azul is still regarded as meso-eutrophic, Lake Verde is considered eutrophic (Santos et al., 2004).

\subsection{Data collection}

Water quality data used in the present work was obtained in 2004 during quarterly sampling field campaigns. Water samples were collected, at surface, $2.5 \mathrm{~m}, 5.0 \mathrm{~m}$, $10.0 \mathrm{~m}, 15.0 \mathrm{~m}$ and $20.5 \mathrm{~m}$, at a sampling point located in the middle of Lake Verde, in the deepest zone, using a Van Dorn bottle with $6 \mathrm{~L}$ capacity. Water samples were analyzed for chemical parameters, such as $\mathrm{PO}_{4}^{3-}, \mathrm{NO}_{3}^{-}$ and $\mathrm{NH}_{4}^{+}$. Chemical analyses were performed according to Standard Methods (APHA, 1998). $\mathrm{PO}_{4}^{3-}$ was analyzed using the spectrophotometric molybdenum blue/stannous chloride method (SMEWW 4500-P), $\mathrm{NO}_{3}^{-}$by the ultraviolet spectrophotometric screening method (SMEWW 4500$\mathrm{NO}_{3}^{-}$), and $\mathrm{NH}_{4}^{+}$by the visible spectrophotometric screening method (SMEWW 4500- $\mathrm{NH}_{3} \mathrm{C}$ ). Temperature and dissolved $\mathrm{O}_{2}$ were determined in situ at several water depths (previously described), with a portable multiparameter meter.

Phytoplankton cell counting was performed in water samples collected at the surface of the lake, after settling, using the inverted microscope method (Utermöhl, 1958). At least 100 specimens of the dominant species were counted (Lund et al., 1958). For biomass determination the mean cell volume of each species was calculated according to Hillebrand et al. (1999). 
Sediment samples were collected at the deepest location of Lake Verde using a gravity Uwitec-corer. The Uwitec-corer tubes, with a diameter of $6 \mathrm{~cm}$ and $60 \mathrm{~cm}$ length, penetrated about $40 \mathrm{~cm}$ into the sediments, collecting the overlaying water as well. The composite sediment/ water samples were sealed in situ, inside the core tubes. Later, in the laboratory, the water from the sampling core tubes was removed and placed in glass flasks that were preserved at $4{ }^{\circ} \mathrm{C}$. The sediment of each core was later cut in five slices with an Uwitec mechanical cutting apparatus and each slice was homogenized and frozen in sealed Petri dishes for further analysis. The sediment density was measured with a He pycnometer (Micromeritics, Pycnometer 1305). To determine the organic fraction and water fraction, $2 \mathrm{~g}$ of sediment were weighed, dried at $105^{\circ} \mathrm{C}$ and re-weighed. Next, the sediments were burned at $550{ }^{\circ} \mathrm{C}$ and weighed a final time.

For $\mathrm{P}$ speciation in the sediments, a modified scheme from Psenner and Pucsko (1988) was used, as proposed by Romero-Gonzalez et al. (2001). This procedure allows the separation of the phosphorus $\mathrm{Fe}$ - and Al-bound fractions from the Ca-bound fraction. The extraction process comprises five steps and allows the fractionation of labile $\mathrm{P}$ (using $\mathrm{NH}_{4} \mathrm{Cl}$ as solvent at room temperature), redoxsensitive $\mathrm{P}$ (using bicarbonate-dithionite as solvent at $40{ }^{\circ} \mathrm{C}$ ), metal oxide bound $\mathrm{P}$ and organically bound $\mathrm{P}$ (using $\mathrm{NaOH}$ as solvent at room temperature), Ca-bound $\mathrm{P}$ (using $\mathrm{HCl}$ as solvent at room temperature) and refractory/residual $\mathrm{P}$ (using $\mathrm{NaOH}$ as solvent at $85^{\circ} \mathrm{C}$ ).

\subsection{Mathematical modelling}

The use of mathematical models in environmental management should lead to the development of lake management policies to reduce the risk of environmental degradation. The model used in the present study is based on the one developed by Omlin et al. (2001a,b) and includes two coupled submodels, one for the water column and another for the adjacent sediment layers. All processes are active in both submodels, but different conversion rates were used. The model was then implemented in AQUASIM simulation and data analysis software (Reichert, 1994).

The present model is based on horizontal average changes in nutrient concentrations $\left(\mathrm{PO}_{4}^{3-}, \mathrm{NO}_{3}^{-}\right.$and $\left.\mathrm{NH}_{4}^{+}\right)$, $\mathrm{O}_{2}$ and organism concentration that are transported in the water column by vertical mixing, sedimentation, inand out-flows and on biogeochemical conversion processes in the water column and in the adjacent sediment layers. Vertical mixing was described as a diffusion process and different values for the diffusion coefficient in summer and winter periods in the epilimnion, metalimnion and upper and lower hypolimnion were defined. The time dependent boundaries between these zones were taken from temperature data. Particulate components are assumed to have a constant sedimentation velocity, which is different for different types of particles. Suspended particles interact with the sediment layers by sedimentation and the diffusive exchange with the sediment pore water affects the concentrations of dissolved substances (Omlin et al., 2001a). The light intensity was assumed to decrease with water depth and the light extinction coefficient depends linearly on the concentration of suspended particles.

The model state variables were $\mathrm{O}_{2}\left(S_{\mathrm{O}_{2}}\right), \mathrm{NH}_{4}^{+}\left(S_{\mathrm{NH}_{4}}\right)$, $\mathrm{NO}_{3}^{-}\left(\mathrm{S}_{\mathrm{NO}_{3}}\right)$ and $\mathrm{PO}_{4}^{3-}\left(S_{\mathrm{HPO}_{4}}\right)$, as dissolved components. As particulate components inert organic matter (non-degradable) $\left(X_{\mathrm{I}}\right)$, degradable organic matter $\left(X_{\mathrm{S}}\right)$ (summarizes organic particles resulting from allochthonous sources, from death of phytoplankton and zooplankton, and from zooplankton excretion as fecal pellets) and organic $\mathrm{P}\left(X_{\mathrm{P}, \text { phyto, }}\right.$ $X_{\mathrm{P}, \mathrm{I}}$ and $X_{\mathrm{P}, \mathrm{S}}$ ) were considered. The $\mathrm{P}$ contents of phytoplankton classes and organic matter are separate state variables because the variable stoichiometry of primary production leads to a variable $P$ content of these particles (Omlin et al., 2001a). In addition, the $P$ content resulting from $\mathrm{PO}_{4}^{3-}$ uptake by sinking particles is considered as a state variable $\left(X_{\mathrm{PI}, \mathrm{S}}\right)$. The biological part of the model is represented by three plankton classes, diatoms $\left(X_{\text {Diat }}\right)$ and cyanobacteria $\left(X_{\text {Cyan }}\right)$ as phytoplankton groups, and zooplankton $\left(X_{\mathrm{Zoo}}\right)$. The major input variables driving the model are presented in Table 1 .

Table 2 illustrates the biogeochemical processes considered in the model and the interactions with the different state variables, namely: aerobic, anaerobic and anoxic mineralization of degradable organic matter, carried out by bacteria; growth, respiration, and mortality of cyanobacteria; growth, respiration and mortality of diatoms; growth, respiration and mortality of zooplankton; bacterial nitrification and lastly $P$ uptake by sinking particles. The rate equations and the respective stoichiometric coefficients are presented in Omlin et al. (2001a). Nutrient and $\mathrm{O}_{2}$ conversion rates were formulated with Monod-type expressions for the transition from unlimited to limited rates.

Model calibration was carried out using a heuristic method; the temperature profile was adjusted firstly, followed by dissolved $\mathrm{O}_{2}$ and $\mathrm{P}$ profiles, in the water column. Phytoplankton biomass, expressed as dry matter concentration of diatoms and cyanobacteria, was calibrated finally. Table 3 shows initial and final values of the major calibrated parameters. The values of the remaining model parameters were taken from Omlin et al. (2001a).

Table 1

Input variables of the model

\begin{tabular}{|c|c|c|}
\hline Description & Value & Units \\
\hline Annual inflow & $7.9 \times 10^{6}$ & $\mathrm{~m}^{3} / \mathrm{yr}$ \\
\hline Input phosphorus concentration & 20 & $\mu \mathrm{g} / \mathrm{L} \mathrm{P}$ \\
\hline Initial phosphorus & 5 & $\mu \mathrm{g} / \mathrm{L} \mathrm{P}$ \\
\hline Initial ammonium & 0.08 & $\mu \mathrm{g} / \mathrm{L} \mathrm{N}$ \\
\hline Initial nitrate & 0.20 & $\mu \mathrm{g} / \mathrm{L} \mathrm{N}$ \\
\hline Initial dissolved oxygen & 10 & $\mathrm{mg} / \mathrm{L}$ \\
\hline $\begin{array}{l}\text { Initial biomass of diatoms } \\
\quad \text { (dry mass without } P \text { ) }\end{array}$ & 1.0 & $\mathrm{mg} / \mathrm{L} \mathrm{DM}^{\mathrm{a}}$ \\
\hline $\begin{array}{l}\text { Initial biomass of cyanobacteria } \\
\text { (dry mass without } P \text { ) }\end{array}$ & 0.1 & $\mathrm{mg} / \mathrm{L} \mathrm{DM}^{\mathrm{a}}$ \\
\hline $\begin{array}{l}\text { Initial inert organic material } \\
\text { (dry mass without } \mathrm{P})\end{array}$ & 0.01 & $\mathrm{mg} / \mathrm{L} \mathrm{DM}^{\mathrm{a}}$ \\
\hline $\begin{array}{l}\text { Initial biodegradable organic material } \\
\text { (dry mass without } \mathrm{P} \text { ) }\end{array}$ & 0.01 & $\mathrm{mg} / \mathrm{L} \mathrm{DM}^{\mathrm{a}}$ \\
\hline Maximum water temperature & 22 & ${ }^{\circ} \mathrm{C}$ \\
\hline Minimum water temperature & 13 & ${ }^{\circ} \mathrm{C}$ \\
\hline
\end{tabular}

a Dry matter. 
Table 2

Biogeochemical processes considered in the model and the respective interactions with the state variables

\begin{tabular}{|c|c|c|}
\hline State variables & Consumption processes & Production processes \\
\hline Ammonium $\left(S_{\mathrm{NH}_{4}}\right) / \mathrm{mg} / \mathrm{L} \mathrm{N}$ & Bacterial nitrification & $\begin{array}{l}\text { Aerobic, anaerobic and anoxic } \\
\text { mineralization } \\
\text { Respiration of diatoms } \\
\text { Respiration of cyanobacteria } \\
\text { Growth and respiration of zooplankton }\end{array}$ \\
\hline Nitrate $\left(S_{\mathrm{NO}_{3}}\right) / \mathrm{mg} / \mathrm{L} \mathrm{N}$ & $\begin{array}{l}\text { Anoxic mineralization } \\
\text { Growth of diatoms } \\
\text { Growth of cyanobacteria }\end{array}$ & Bacterial nitrification \\
\hline Phosphate $\left(S_{\mathrm{HPO}_{4}}\right) / \mathrm{mg} / \mathrm{L} \mathrm{P}$ & $\begin{array}{l}\text { Growth of diatoms } \\
\text { Growth of cyanobacteria } \\
\text { Phosphorus uptake by sinking particles }\end{array}$ & $\begin{array}{l}\text { Aerobic, anaerobic and anoxic } \\
\text { mineralization } \\
\text { Respiration of diatoms } \\
\text { Respiration of cyanobacteria } \\
\text { Growth and respiration of zooplankton }\end{array}$ \\
\hline $\begin{array}{l}\text { Organic phosphorus in biodegradable organic materia }\left(X_{\mathrm{P}, \mathrm{S}}\right) / \\
\mathrm{mg} / \mathrm{L} \mathrm{P}\end{array}$ & $\begin{array}{l}\text { Aerobic, anaerobic and anoxic } \\
\text { mineralization }\end{array}$ & $\begin{array}{l}\text { Mortality of cyanobacteria } \\
\text { Mortality of diatoms } \\
\text { Growth and mortality of zooplankton }\end{array}$ \\
\hline Organic phosphorus in inert organic material $\left(X_{\mathrm{P}, \mathrm{I}}\right) / \mathrm{mg} / \mathrm{L} \mathrm{P}$ & - & $\begin{array}{l}\text { Mortality of cyanobacteria } \\
\text { Mortality of diatoms } \\
\text { Mortality of zooplankton }\end{array}$ \\
\hline Organic phosphorus in phytoplankton $\left(X_{\mathrm{P}, \text { phyto }}\right) / \mathrm{mg} / \mathrm{L} \mathrm{P}$ & $\begin{array}{l}\text { Respiration and mortality of diatoms } \\
\text { Respiration and mortality of } \\
\text { cyanobacteria } \\
\text { Growth of zooplankton }\end{array}$ & $\begin{array}{l}\text { Growth of diatoms } \\
\text { Growth of cyanobacteria }\end{array}$ \\
\hline $\begin{array}{l}\text { Phosphate attached to biodegradable organic material }\left(X_{\mathrm{PI}}\right) / \\
\mathrm{mg} / \mathrm{L} \mathrm{P}\end{array}$ & $\begin{array}{l}\text { Aerobic, anaerobic and anoxic } \\
\text { mineralization }\end{array}$ & Phosphorus uptake by sinking particles \\
\hline Dissolved oxygen $\left(S_{\mathrm{O}_{2}}\right) / \mathrm{mg} / \mathrm{L}$ & $\begin{array}{l}\text { Aerobic mineralization } \\
\text { Respiration of diatoms } \\
\text { Respiration of cyanobacteria } \\
\text { Growth and respiration of zooplankton } \\
\text { Bacterial nitrification }\end{array}$ & $\begin{array}{l}\text { Growth of diatoms } \\
\text { Growth of cyanobacteria }\end{array}$ \\
\hline Degradable organic matter $\left(X_{\mathrm{S}}\right) / \mathrm{mg} / \mathrm{L} \mathrm{DM}^{\mathrm{a}}$ & $\begin{array}{l}\text { Aerobic, anaerobic and anoxic } \\
\text { mineralization }\end{array}$ & $\begin{array}{l}\text { Mortality of diatoms } \\
\text { Mortality of cyanobacteria } \\
\text { Growth and Mortality of zooplankton }\end{array}$ \\
\hline Inert organic matter $\left(X_{\mathrm{I}}\right) / \mathrm{mg} / \mathrm{L} \mathrm{DM}^{\mathrm{a}}$ & - & $\begin{array}{l}\text { Mortality of diatoms } \\
\text { Mortality of cyanobacteria } \\
\text { Mortality of zooplankton }\end{array}$ \\
\hline Diatoms $\left(X_{\text {Diat }}\right) / \mathrm{mg} / \mathrm{L} \mathrm{DM}^{\mathrm{a}}$ & $\begin{array}{l}\text { Respiration and mortality of diatoms } \\
\text { Growth of zooplankton }\end{array}$ & Growth of diatoms \\
\hline Cyanobacteria $\left(X_{\text {Cyan }}\right) / \mathrm{mg} / \mathrm{L} \mathrm{DM}^{\mathrm{a}}$ & $\begin{array}{l}\text { Respiration and mortality of } \\
\text { cyanobacteria }\end{array}$ & Growth of cyanobacteria \\
\hline Zooplankton $\left(X_{\text {Zoo }}\right) / \mathrm{mg} / \mathrm{L} \mathrm{DM}^{\mathrm{a}}$ & Respiration and mortality of zooplankton & Growth of zooplankton \\
\hline
\end{tabular}

a Dry matter.

\subsection{Scenarios design}

Eutrophication caused by P loads into surface water bodies can be minimized by the implementation of external measures (reduction of incoming loads) and internal measures (reduction of organic content of sediments). Therefore, in order to carry out an evaluation of policies based on external and internal measures, four scenarios for the next 10 years were developed for the Lake Verde. The scenario control was based on actual conditions; the scenario PORAL (Operational Program for Lake Requalification) is associated with a reduction of the $P$ input to Lake Verde (the P load was reduced 50\%, from $432 \mathrm{~g} / \mathrm{d}$ to $216 \mathrm{~g} / \mathrm{d}$ of $\mathrm{P}$ ); the scenario sediments foresees a reduction in the organic fraction of sediments from $18 \%$ to $9 \%$ to simulate the effect of changing sediment composition on $\mathrm{P}$ release and, finally, the scenario PORAL + sediments combines the previous scenarios.

\subsection{Sensitivity analysis}

A sensitivity analysis of the model parameters was carried out using the absolute-relative sensitivity function (Sens AR). The Sens AR measures the absolute change in a state variable for a $100 \%$ change in a model parameter and does not depend on the parameter units (Reichert, 1998). The parameters are varied independently to assess how these changes affect the model results. The calculations were performed with AQUASIM.

A sensitivity analysis was conducted for all model parameters (Table 3 ) and was focused only on the water column. The parameters were grouped in three classes of 
Table 3

Values of the major calibrated parameters

\begin{tabular}{|c|c|c|c|}
\hline Description & $\begin{array}{l}\text { Initial } \\
\text { value }\end{array}$ & $\begin{array}{l}\text { Final } \\
\text { value }\end{array}$ & Units \\
\hline $\begin{array}{l}\text { Fraction of degradable organic matter } \\
\text { in the sediment }\left(a_{\text {deg,sed,ini }}\right)\end{array}$ & 0.40 & 0.18 & - \\
\hline $\begin{array}{l}\text { Parameter for switching to production } \\
\text { with reduced P content }\left(\Delta S_{\mathrm{HPO}_{4}}\right)\end{array}$ & 0.0013 & 0.0030 & $\mathrm{mg} / \mathrm{L} \mathrm{P}$ \\
\hline Thickness of sediment layers $\left(h_{\text {sed }}\right)$ & 0.0036 & 0.01 & $\mathrm{~m}$ \\
\hline Maximum solar radiation $\left(I_{\max }\right)$ & 200 & 250 & $\mathrm{~W} / \mathrm{m}^{2}$ \\
\hline Minimum solar radiation $\left(I_{\min }\right)$ & 40 & 50 & $\mathrm{~W} / \mathrm{m}^{2}$ \\
\hline $\begin{array}{l}\text { Light extinction coefficient in the } \\
\text { absence of particles }\left(k_{1}\right)\end{array}$ & 0.31 & 0.50 & $1 / \mathrm{m}$ \\
\hline $\begin{array}{l}\text { Diatoms maximum specific growth } \\
\text { rate at } 20^{\circ} \mathrm{C}\left(k_{\text {gro,Diat,20 }}\right)\end{array}$ & 1.10 & 1.14 & $1 / d$ \\
\hline $\begin{array}{l}\text { Cyanobacteria maximum specific } \\
\text { growth rate at } 20^{\circ} \mathrm{C}\left(k_{\text {gro,Cyan,20 }}\right)\end{array}$ & 1.10 & 1.00 & $1 / \mathrm{d}$ \\
\hline $\begin{array}{l}\text { Diatoms Monod coefficient for } \\
\qquad \mathrm{HPO}_{4}\left(K_{\mathrm{HPO}_{4} \text {,Diat }}\right)\end{array}$ & 0.0019 & 0.0020 & $\mathrm{mg} / \mathrm{L}$ \\
\hline $\begin{array}{l}\text { Cyanobacteria Monod coefficient for } \\
\qquad \mathrm{HPO}_{4}\left(K_{\mathrm{HPO}_{4}, \text { Cyan }}\right)\end{array}$ & 0.0019 & 0.0020 & $\mathrm{mg} / \mathrm{L}$ \\
\hline $\begin{array}{l}\text { Diatoms half saturation rate } \\
\text { for light intensity }\left(K_{\mathrm{I}, \text { diat }}\right)\end{array}$ & 34 & 5 & $\mathrm{~W} / \mathrm{m}^{2}$ \\
\hline $\begin{array}{l}\text { Cyanobacteria half saturation rate } \\
\text { for light intensity }\left(K_{\mathrm{I}, \text { cyan }}\right)\end{array}$ & 20 & 5 & $\mathrm{~W} / \mathrm{m}^{2}$ \\
\hline $\begin{array}{l}\text { Diatoms half saturation rate for } \mathrm{NO}_{3} \\
\left(K_{\mathrm{NO}_{3} \text {,Diat }}\right)\end{array}$ & 0.040 & 0.050 & $\mathrm{mg} / \mathrm{L}$ \\
\hline $\begin{array}{l}\text { Cyanobacteria half saturation rate for } \\
\qquad \mathrm{NO}_{3}\left(K_{\mathrm{NO}_{3}, \text { Cyan }}\right)\end{array}$ & 0.040 & 0.045 & $\mathrm{mg} / \mathrm{L}$ \\
\hline $\begin{array}{l}\text { Cyanobacteria maximum specific respiration } \\
\text { rate at } 20^{\circ} \mathrm{C}\left(k_{\mathrm{resp}, \mathrm{Cyan}, 20}\right)\end{array}$ & 0.05 & 0.10 & $1 / \mathrm{d}$ \\
\hline Diffusion coefficient for epilimnion $(K z$,epi $)$ & 200 & 5.0 & $\mathrm{~m}^{2} / \mathrm{d}$ \\
\hline Diffusion coefficient for metalimnion $(K z$,met $)$ & 0.2 & 0.3 & $\mathrm{~m}^{2} / \mathrm{d}$ \\
\hline Diffusion coefficient for hypolimnion ( $\left.K z_{\text {,hyp }}\right)$ & 2.0 & 0.3 & $\mathrm{~m}^{2} / \mathrm{d}$ \\
\hline Sediments porosity $(\theta)$ & 0.95 & 0.90 & - \\
\hline Time of minimum temperature ( $\left.t_{\text {min,temp }}\right)$ & 30 & 15 & $\mathrm{~d}$ \\
\hline
\end{tabular}

standard deviation, according to their accuracy (Omlin et al., 2001b): accurately known parameters (5\%), very poorly known parameters (50\%), and an intermediate class of moderately inaccurate parameters $(20 \%)$. A general criterion was used in order to classify stoichiometric and specific growth rate parameters as moderately inaccurate parameters and the other kinetic parameters as very poorly known parameters. Input-related parameters were typically classified as moderately inaccurate parameters. Physical parameters, like sediment porosity, thickness of sediment layer, light extinction coefficient and maximum and minimum solar radiation, were classified as accurately known parameters. To estimate the uncertainty of the prospective scenarios, standard deviations of the model results were determined using the error propagation method as described by Reichert (1998).

\section{Results and discussion}

\subsection{Sediments characterization}

The sediments of Lake Verde have a density of $2.44 \mathrm{~kg} / \mathrm{L}$ and an organic content of $18 \%$. Fig. 1 shows the results of $P$ speciation in the lake sediments. The distribution of $\mathrm{P}$ fractions in the different sediment layers is fairly homogeneous with the exception of the fraction extracted by $\mathrm{NH}_{4} \mathrm{Cl}$ that decreased from $17 \%$ in the top layer to $4 \%$ in the bottom layer. The $\mathrm{NH}_{4} \mathrm{Cl}-\mathrm{P}$ fraction corresponds to $\mathrm{P}$ in the interstitial water and to $\mathrm{PO}_{4}$ weakly adsorbed onto the sediment surfaces. It can be released to the water column by a decrease in $\mathrm{pH}$ verified during anoxic conditions in the hypolimnion contributing to the occurrence of algae blooms (Gonsiorczyk et al., 1998). The $\mathrm{NaOH}$ extraction (at room temperature) resulted in the highest amount of $\mathrm{P}$ (49\%) that is both bound to metal oxides (25\%) and incorporated into biomass and detritus (24\%). The presence of $\mathrm{P}$ bound to $\mathrm{Al}$ and Fe oxides in sediments from Lake Verde was reported by Cruz et al. (2006). This fraction can be released to the water column under reductive conditions in the hypolimnium due to low $\mathrm{O}_{2}$ concentrations (Wang et al., 2006). It is important to note that $46 \%$ of the $P$ extracted in all steps was bound to organic material and that was the only P-fraction considered in the model described above.

Lake water quality models often describe the processes occurring in the sediments in less detail than the ones occurring in the water column. Usually, only the mineralization process is considered in the sediments (Omlin et al., 2001a) as is the case for the present model. However, other significant P-fractions present in the sediments, as reported in the present work, might be released to the water column by several biological and physic-chemical processes (Kim et al., 2003) that need to be included in the model in the near future.

\subsection{Model calibration}

\subsubsection{Physical-chemical quality}

Temperature, dissolved $\mathrm{O}_{2}$ and $\mathrm{PO}_{4}^{3-}$ concentration profiles along the water column experimentally observed and simulated are shown in Figs. 2-4. Lake Verde undergoes seasonal thermal stratification that extends between May and November (Fig. 2) otherwise the lake is completely mixed. The surface water temperature varies from $14^{\circ} \mathrm{C}$ in February to $22^{\circ} \mathrm{C}$ in July. During stratification, the temperature difference between the surface and bottom of the lake is around $4{ }^{\circ} \mathrm{C}$ in May and $7{ }^{\circ} \mathrm{C}$ in July. The dissolved $\mathrm{O}_{2}$ profiles (Fig. 3 ) show that $\mathrm{O}_{2}$ concentration at the lake bottom was very low in July due to stratification. At the lake surface the lowest value of $\mathrm{O}_{2}$ concentration $(7.8 \mathrm{mg} / \mathrm{L})$ was recorded in November with the highest one $(9.7 \mathrm{mg} /$ $\mathrm{L}$ ) in February. During summer, both temperature and dissolved $\mathrm{O}_{2}$ values (Figs. 2 and 3) simulated at the lake bottom (approximately $15^{\circ} \mathrm{C}$ and less than $1 \mathrm{mg} / \mathrm{L}$ ) were lower than those at the surface (approximately $22{ }^{\circ} \mathrm{C}$ and $9 \mathrm{mg} / \mathrm{L}$ ), consistent with the stratification conditions occurring during this period. Concerning temperature and $\mathrm{O}_{2}$ profiles, there was no significant difference in the simulated profiles and the experimental data. However, in November, the simulated profile for dissolved $\mathrm{O}_{2}$ showed a deviation from the experimental data. Under anoxic conditions at the lake bottom, $P$ was released from sediments into the hypolimnion and accumulated there due to mass transfer limitations between the epilimnion and hypolimnion (Fig. 4). Phosphate concentration at the lake bottom was $88 \mu \mathrm{g} / \mathrm{L}$ P in November compared to $7 \mu \mathrm{g} / \mathrm{L}$ P in May. The model predicted experimental $\mathrm{PO}_{4}^{3-}$ profiles (Fig. 4) and flux of $\mathrm{PO}_{4}^{3-}$ from the sediments quite well. However, $\mathrm{PO}_{4}^{3-}$ concentrations at the lake bottom in May and in 


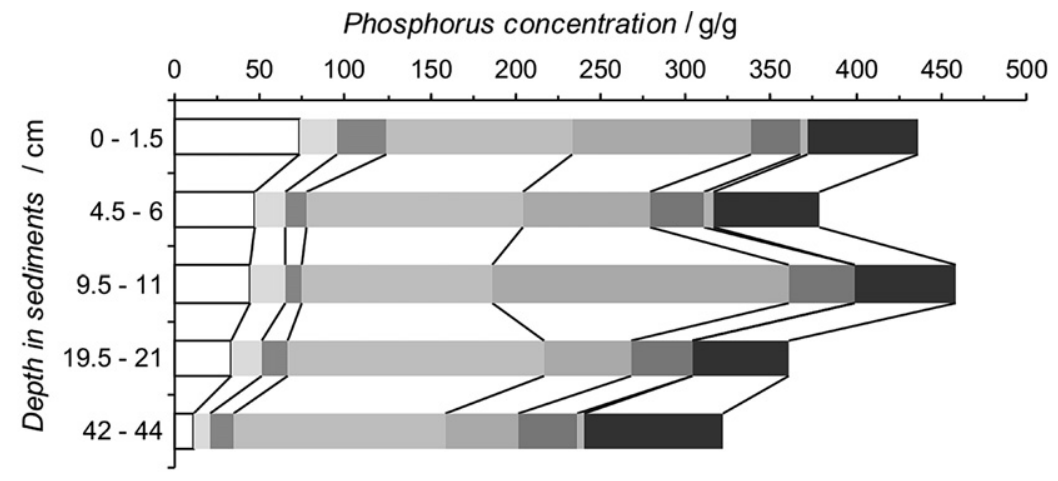

$\square \mathrm{NH} 4 \mathrm{Cl}-\mathrm{TP} \backsim \mathrm{BD}-\mathrm{SRP} \square \mathrm{BD}-\mathrm{NRP} \backsim \mathrm{NaOH}-\mathrm{SRP} \backsim \mathrm{NaOH}-\mathrm{NRP} \square \mathrm{HCl}-\mathrm{SRP} \backsim \mathrm{HCl}-\mathrm{NRP} \square \mathrm{NaOH}-\mathrm{TP} 85^{\circ} \mathrm{C}$

Fig. 1. Phosphorus fractionation at different sediment depths from Lake Verde expressed as mass of P per mass of sediment. (SRP - soluble reactive P; TP total P; NRP - non-reactive P).

A

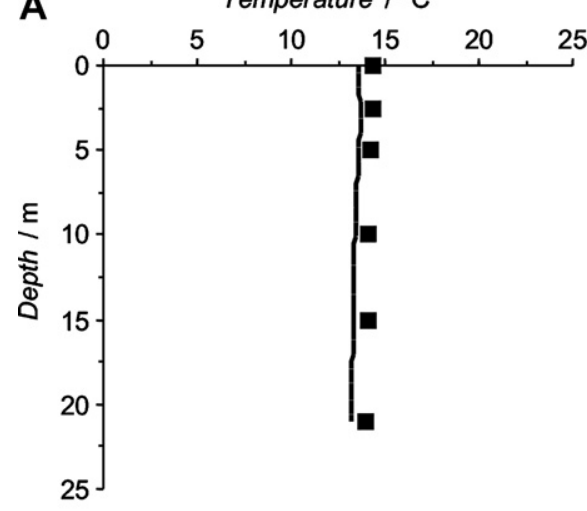

B

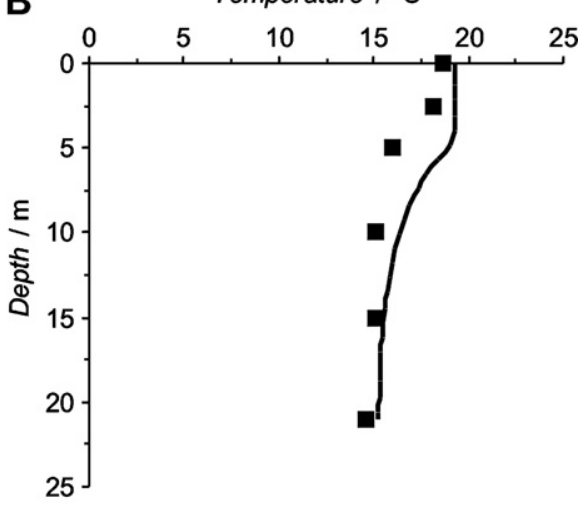

C

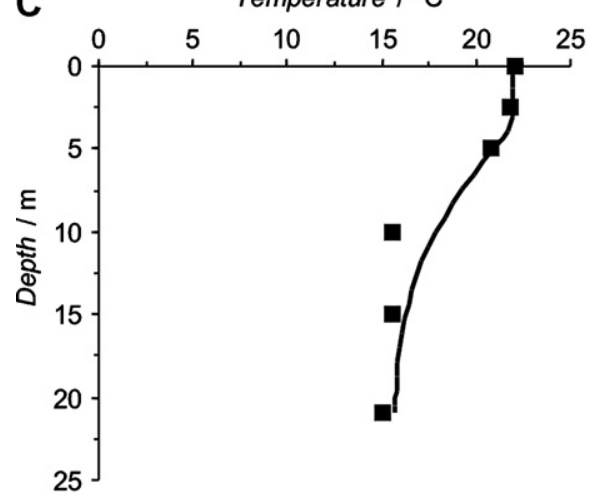

D

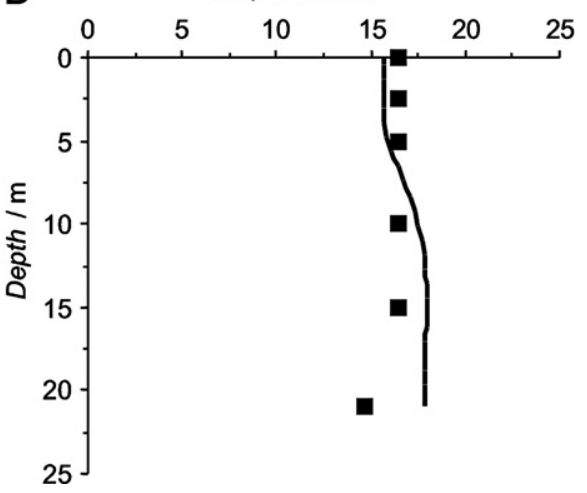

Fig. 2. Temperature profiles: (A) February 17; (B) May 11; (C) July 7; (D) November 10. Markers ( $\mathbf{\square})$ represent experimental data and lines (一) predicted values.

November are exceptions. In May, the concentration was higher than expected while in November the opposite happened. These differences might be due to the low number of experimental data points available for calibration. To calibrate temperature and $\mathrm{O}_{2}$ profiles lake destratification was imposed sooner than was expected with regard of the $\mathrm{PO}_{4}^{3-}$ profiles.

To assess the organic $P$ fraction in the sediments, the maximum concentration of $P$ predicted at the lake bottom was compared with the one obtained by the maximum sol- ubilisation potential (MSP) assessment test described in Ribeiro et al. (2008). The MSP was calculated for each organic P fraction, respectively, $29 \mu \mathrm{g} / \mathrm{L}$ for BD-NRP, $102 \mu \mathrm{g} /$ $\mathrm{L}$ for $\mathrm{NaOH}-\mathrm{NRP}$ at room temperature, $3 \mu \mathrm{g} / \mathrm{L}$ for $\mathrm{HCl}-$ $\mathrm{NRP}$ and $64 \mu \mathrm{g} / \mathrm{L}$ for $\mathrm{NaOH}-\mathrm{TP}$ at $80^{\circ} \mathrm{C}$. In the calculations a $10 \mathrm{~mm}$ thick sediment layer was considered as well as a water column of $2.5 \mathrm{~m}$ corresponding to the upper hypolimnion bound. Interestingly, the maximum $\mathrm{P}$ concentration predicted in the lake bottom, $105 \mu \mathrm{g} / \mathrm{L}$, was similar to the MSP of the NaOH-NRP ( $\mathrm{P}$ in microorganisms and 
A

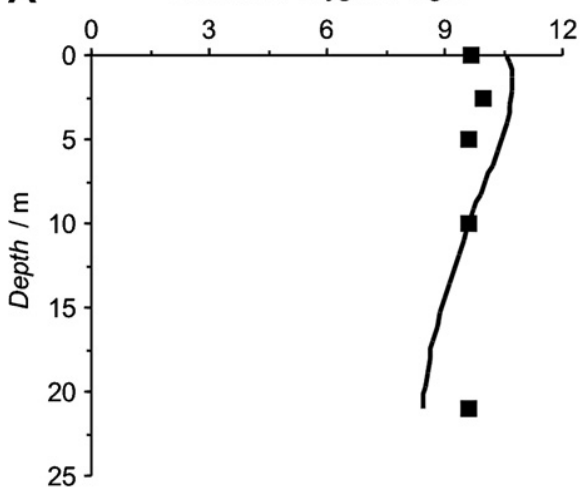

C

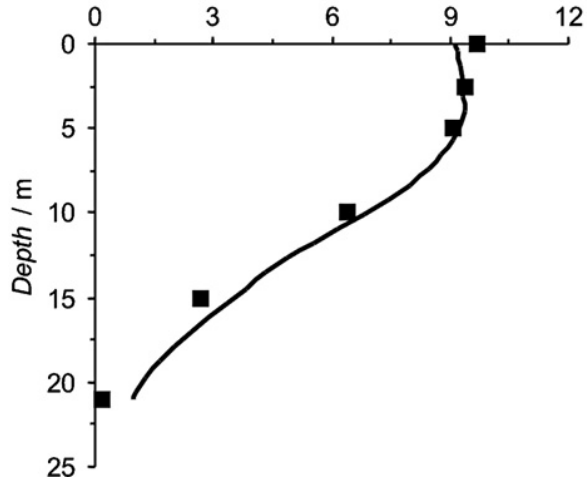

B Dissolved oxygen / mg/L
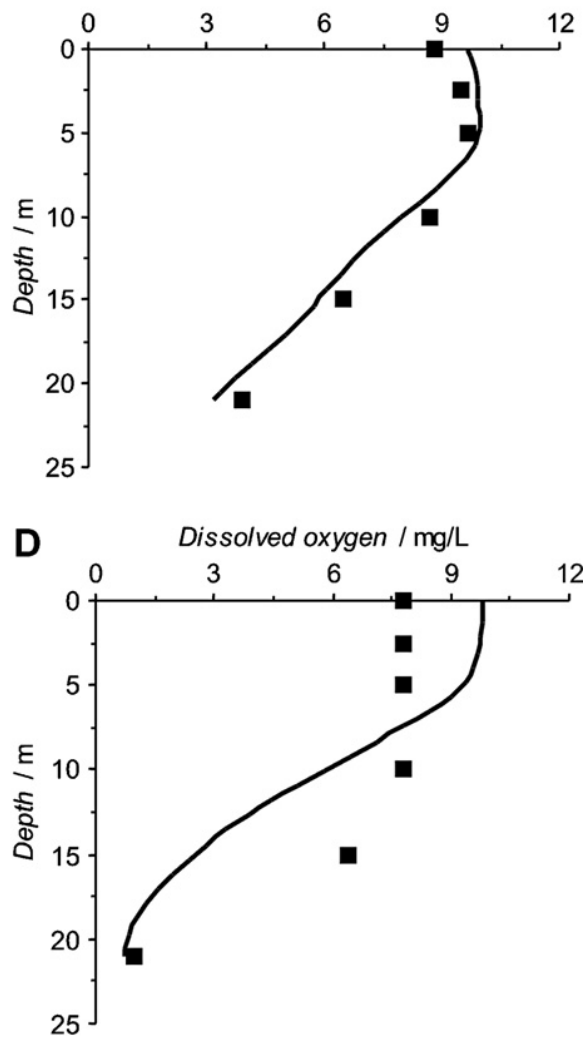

Fig. 3. Dissolved $\mathrm{O}_{2}$ profiles: (A) February 17; (B) May 11; (C) July 7; (D) November 10. Markers ( $\left.\mathbf{\square}\right)$ represent experimental data and lines ( - ) predicted values.

detritus plus phosphates bound to humic material), $102 \mu \mathrm{g} / \mathrm{L}$. The sum of all organic fractions has a MSP of $200 \mu \mathrm{g} / \mathrm{L}$ that is higher than the predicted P concentration in the lake bottom. Considering that the $\mathrm{P}$ present in the fractions $\mathrm{HCl}-\mathrm{NRP}$ and $\mathrm{NaOH}-\mathrm{TP}$ at $80^{\circ} \mathrm{C}$ might not be released to the water column under $\mathrm{pH}$ and temperature conditions present in the lake, the MSP of the NaOH-NRP fraction is a reasonably good approximation of the predicted value.

\subsubsection{Ecological quality}

In general, species belonging to the diatom and cyanobacteria groups dominate the Lake Verde phytoplankton. The community was mostly composed of Asterionella formosa, Fragilaria delicatissima, Fragilaria crotonensis as diatom species and by Woronichinea naegeliana, Microcystis flos-aquae and Aphanizomenon flos-aquae as cyanobacteria species. The experimental observations and the predicted values of phytoplankton biomass at the surface of Lake Verde are depicted in Fig. 5. Diatom biomass concentration remained approximately constant throughout the year, varying between $0.96 \mathrm{mg} / \mathrm{L}$ in June and $1.60 \mathrm{mg} / \mathrm{L}$ in March. The concentration of cyanobacteria was lower than that of diatoms during autumn and winter (between $0.33 \mathrm{mg} / \mathrm{L}$ and $0.46 \mathrm{mg} / \mathrm{L}$ ) but increased later reaching a maximum value of $1.78 \mathrm{mg} / \mathrm{L}$ after June and dominated the phytoplanktonic biomass. The cyanobacteria bloom was probably provoked by both an increase of water tem- perature and availability of $\mathrm{P}$ at the lake surface (Mukhopadhyay and Bhattacharyya, 2006).

The predicted results of phytoplankton dynamics indicated that diatoms were the predominant group in the lake during autumn and winter, while cyanobacteria dominated during spring and summer, with the exception of September. The cyanobacteria bloom was simulated in late March, beginning of April, and occurred when P concentration at the lake surface reached its highest value $(4.4 \mu \mathrm{g} / \mathrm{L})$. The predicted maximum cyanobacteria biomass concentration occurred before the observed result, a discrepancy that could be mitigated if more experimental data points were available to calibrate the ecological model component, despite the fact that many authors have reported deviations in the order of $45 \%$ between predicted and observed results for phytoplankton dynamics (Jørgensen et al., 2002; Gurkan et al., 2006).

\subsection{Sensitivity analysis}

The results of the sensitivity analysis carried out to assess the effect of the different parameters on state variables are presented in Table 4 .

As depicted in Table 4, the parameters that significantly affect the state variables considered in the sensitivity analysis are sediment porosity $(\theta)$, light extinction coefficient $\left(k_{1}\right)$, maximum specific growth rate of cyanobacteria $\left(k_{\text {gro,Cyan,20c }}\right)$, maximum specific growth rate of diatoms 
A

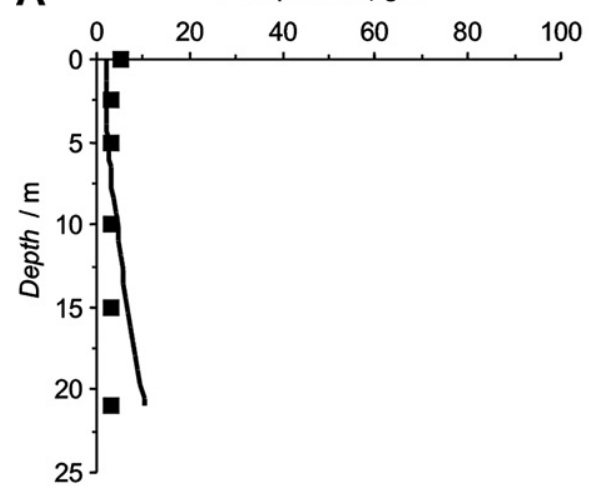

C

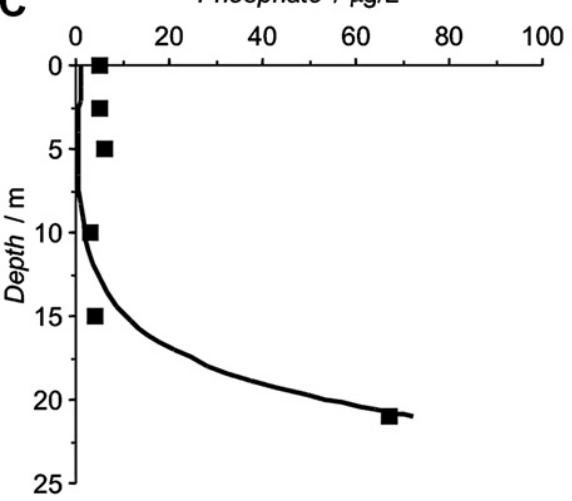

B
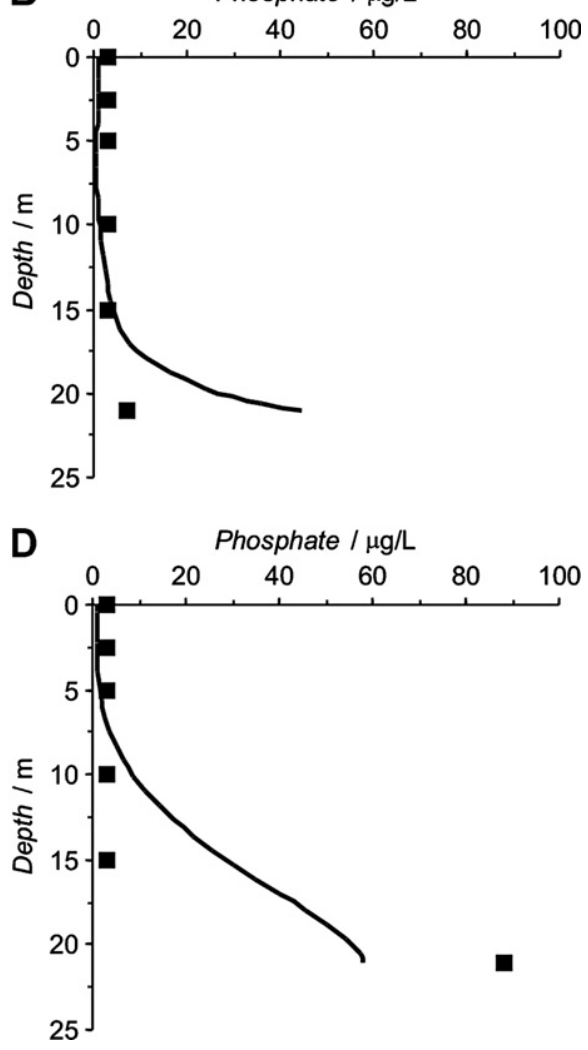

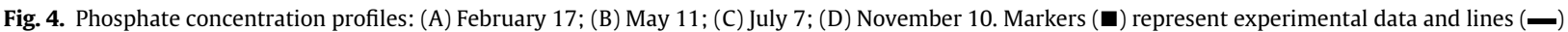
predicted values.

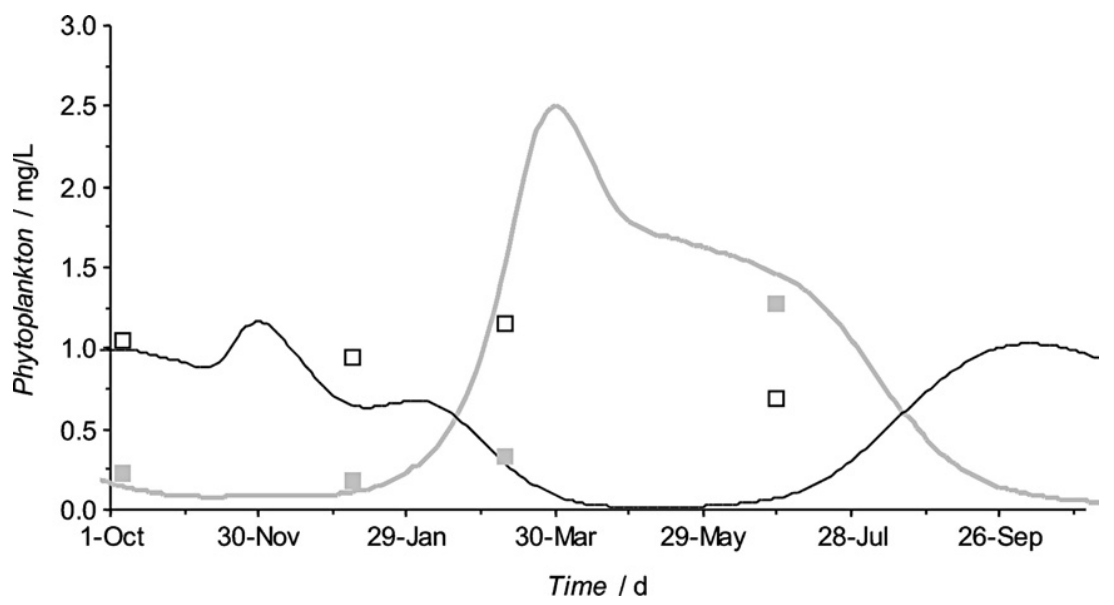

Fig. 5. Phytoplankton dynamics on the surface of Lake Verde during the hydrologic year of 2003/2004. The black line (-) and marker ( $\square$ ) represent predicted and observed values of diatom biomass; the gray line $(-)$ and marker $(\square)$ predicted and observed values of cyanobacteria biomass.

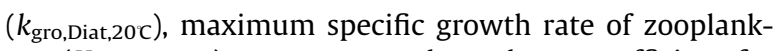
ton $\left(K_{\text {gro,ZOo,20c }}\right)$, temperature dependence coefficient for bacteria $\left(\beta_{\mathrm{BAC}}\right)$, and sediment anaerobic specific mineralization rate $\left(k_{\text {miner,anae,sed,20c }}\right)$. The increase in sediment porosity positively affects the degradation of organic matter leading to both an increase in sediment $\mathrm{O}_{2}$ consumption and in $\mathrm{P}$ release from sediments. The resulting increase of $\mathrm{P}$ in the water column favours phytoplankton growth. The temperature dependence coefficient for bacteria and the sediment anaerobic specific mineralization rate also influence the mineralization process in sediments, although the effect is less significant than the one of sediment porosity. The light extinction coefficient influences the time at which the cyanobacteria peak concentration occurs and its intensity. Parameters related to phytoplankton growth all have a high sensitivity. Finally, it was also 
Table 4

Absolute-relative sensitivity (Sens AR) values of model parameters for water column

\begin{tabular}{|c|c|c|c|c|}
\hline \multirow[t]{2}{*}{ Parameter } & \multicolumn{4}{|c|}{ State variables [effect ${ }^{\mathrm{a}}$, (absolute value)] } \\
\hline & $\begin{array}{l}\text { Oxygen/ } \\
\mathrm{mg} / \mathrm{L}\end{array}$ & $\begin{array}{l}\text { Phosphate/ } \\
\mu \mathrm{g} / \mathrm{L} \mathrm{P}\end{array}$ & $\begin{array}{l}\text { Diatoms/ } \\
\text { mg/L WM }\end{array}$ & $\begin{array}{l}\text { Cyanobacteria/ } \\
\text { mg/L WM }\end{array}$ \\
\hline$a_{\text {deg,sed,ini }}$ & $-(0.00)$ & $-(0.00)$ & $-(0.00)$ & $-(0.00)$ \\
\hline$\Delta S_{\mathrm{HPO}_{4}}$ & $+(0.68)$ & $-(4.05)$ & $+(1.34)$ & $++(2.57)$ \\
\hline$h_{\text {sed }}$ & $+(0.68)$ & $-(3.59)$ & $+(0.77)$ & $+(1.51)$ \\
\hline$I_{\max }$ & $-(0.28)$ & $-(2.02)$ & $-(0.21)$ & $-(0.54)$ \\
\hline$I_{\min }$ & $-(0.13)$ & $-(1.13)$ & $-(0.33)$ & $-(0.44)$ \\
\hline$k_{1}$ & $+(1.56)$ & $+(10.24)$ & $+(1.00)$ & $+(2.31)$ \\
\hline$k_{\text {gro,Diat,20 C }}$ & $+(1.39)$ & $+(7.37)$ & $++(4.84)$ & $++(5.90)$ \\
\hline$k_{\text {gro,Cyan,20 c }}$ & $+(1.53)$ & $+(8.09)$ & $++(5.81)$ & $++(7.15)$ \\
\hline$K_{\mathrm{HPO}_{4} \text {, Diat }}$ & $+(0.80)$ & $+(4.66)$ & $++(4.28)$ & $++(4.41)$ \\
\hline$K_{\mathrm{HPO}_{4}, \text { Cyan }}$ & $+(0.79)$ & $+(4.82)$ & $++(3.10)$ & $++(3.76)$ \\
\hline$K_{\mathrm{I} \text {,diat }}$ & $+(0.56)$ & $-(1.55)$ & $+(0.47)$ & $+(1.69)$ \\
\hline$K_{\mathrm{I}, \text { cyan }}$ & $-(0.30)$ & $-(2.51)$ & $+(0.45)$ & $+(1.62)$ \\
\hline$K_{\mathrm{NO}_{3}, \text { Diat }}$ & $+(1.08)$ & $+(4.64)$ & $++(4.32)$ & $++(5.75)$ \\
\hline$K_{\mathrm{NO}_{3}, \text { Cyan }}$ & $+(0.95)$ & $-(4.44)$ & $++(3.63)$ & $++(5.43)$ \\
\hline$k_{\text {resp,Cyan,20c }}$ & $+(0.96)$ & $+(5.81)$ & $++(3.62)$ & $++(5.07)$ \\
\hline$\theta$ & $++(5.82)$ & $++(51.98)$ & $++(6.55)$ & $++(19.14)$ \\
\hline$K_{\text {gro,Zoo,20c }}$ & $+(1.53)$ & $-(3.85)$ & $++(2.74)$ & $++(5.41)$ \\
\hline$k_{\text {miner,anae,sed,20 c }}$ & $+(0.95)$ & $+(12.37)$ & $+(1.12)$ & $++(2.97)$ \\
\hline$\beta_{\mathrm{BAC}}$ & $+(1.05)$ & $+(11.83)$ & $+(1.21)$ & $++(3.20)$ \\
\hline
\end{tabular}

a Insignificant effect; + moderate effect; ++ significant effect.

observed that the model did not reveal sensitivity to the fraction of degradable organic matter in the sediment. This result might be explained by the fact that this parameter influences only the initial concentration of organic matter in sediments.

\subsection{Prospective scenarios}

In order to achieve the goal of the present work, four prospective scenarios for water and ecological quality assessment of Lake Verde during the next 10 years were developed: the scenario control, the scenario PORAL, the scenario sediments and the scenario PORAL + sediments. It can be observed in Fig. 6 that water quality will deteriorate without the adoption of remediation measures (scenario control), the annual average concentration of total $\mathrm{P}$ in- creases from $19 \mu \mathrm{g} / \mathrm{L}$ at present to $34 \mu \mathrm{g} / \mathrm{L}$ in 10 years. As a consequence, the intensity of cyanobacteria blooms will increase, as depicted in Fig. 7A. The adoption of external remediation measures foreseen in scenario PORAL, consisting in the reduction to half of $P$ loads into the lake, lead to a smaller increase of total $\mathrm{P}$ than in scenario control, from $19 \mu \mathrm{g} / \mathrm{L}$ at present to $26 \mu \mathrm{g} / \mathrm{L}$ in 10 years. The effect of the reduction in the organic fraction of sediments (scenario sediments) from $18 \%$ to $9 \%$ is transitory. During the first 2 years, the concentration of total P decreases from $19 \mu \mathrm{g} / \mathrm{L}$ to $14 \mu \mathrm{g} / \mathrm{L}$. Afterwards it increases steadily due to deposition of organic matter that gradually reaches sediments and mineralizes with the consequent release of P. As expected, the best remediation strategy was achieved by the combination of scenarios PORAL and sediments (Fig. 6D), the annual average concentration of total $P$ decreases from $19 \mu \mathrm{g} / \mathrm{L}$ at present to $16 \mu \mathrm{g} / \mathrm{L}$ in 10 years. As can be seen, both strategies PORAL and PORAL + sediments will improve water quality. The predicted results show a significant reduction in the peak value of total $\mathrm{P}$ from $190 \mu \mathrm{g} / \mathrm{L}$, in scenario control, to $138 \mu \mathrm{g} / \mathrm{L}$, in scenario POR$A L$, and $131 \mu \mathrm{g} / \mathrm{L}$, in scenario PORAL + sediments, in a 10years horizon. In scenario sediment although a significant reduction in the peak value of total $P$ occurs in the first 5 years $(155 \mu \mathrm{g} / \mathrm{L})$ comparatived to scenario control $(171 \mu \mathrm{g} / \mathrm{L})$, by the end of 10 years the two peak values are no longer significantly different.

Regarding the dynamics of phytoplankton growth (Fig. 7), the simulated results for scenarios PORAL and PORAL + sediments show that the reduction of $\mathrm{P}$ loads into the lake did not have a significant effect on the intensity of cyanobacteria peaks. In the extreme situation, where the external P load was completely eliminated, the amount of $P$ released from the sediments was not sufficient to promote cyanobacteria blooms. In scenarios control and sediments the annual average concentration of diatoms is lower than in scenarios PORAL and PORAL + sediments which is due to the lower intensity of the cyanobacteria blooms verified in the first years of simulation. The predicted results show a reduction of the annual average concentration of phytoplankton from $2 \mathrm{mg} / \mathrm{L}$, in scenario control, to $1.4 \mathrm{mg} / \mathrm{L}$, in both scenarios $P O R A L$ and

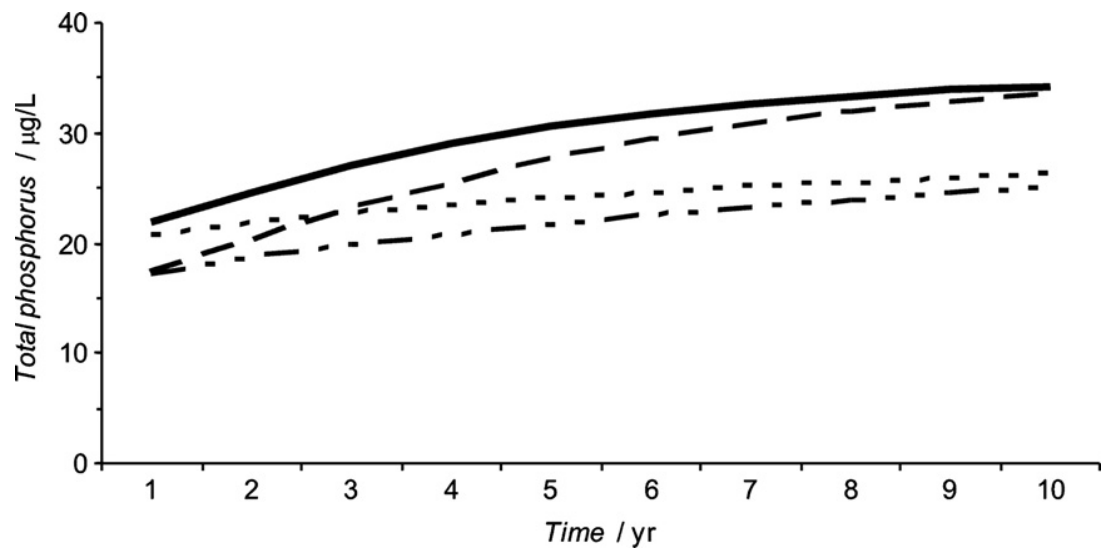

Fig. 6. Predicted average values of total P concentration in Lake Verde for scenario control (-), scenario PORAL (- - -), scenario sediments (- - -) and for scenario PORAL + sediments (- - - ). 

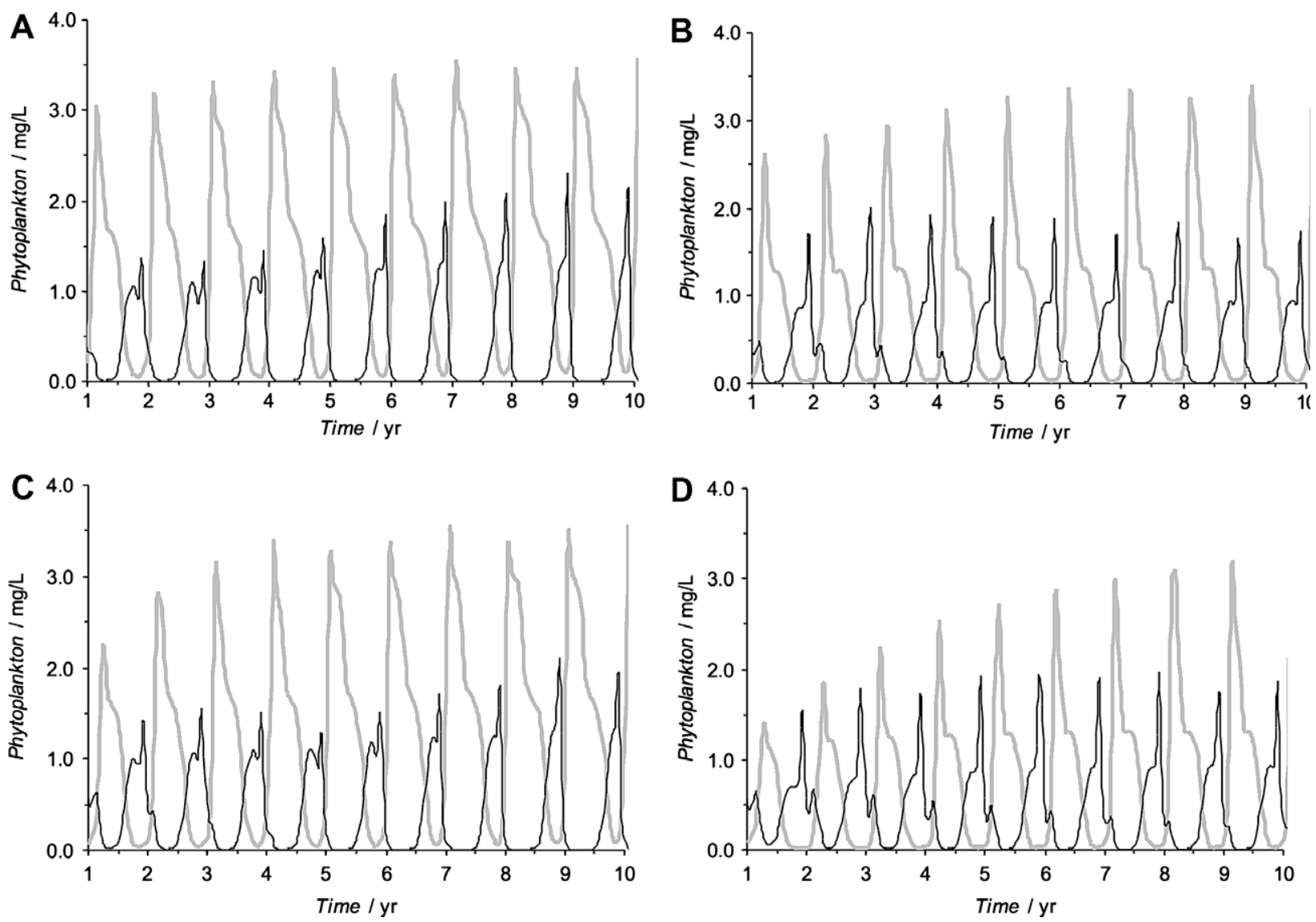

Fig. 7. Predicted phytoplankton dynamics in Lake Verde for scenario control (A), scenario PORAL (B), scenario sediments (C) and for scenario PORAL + sediments (D). The black line (-) represents the diatoms and the gray line $(-)$ represents the cyanobacteria.

PORAL + sediments, in a 10 -years horizon. The initial differences between observed between scenario control and scenario sediments vanished in a 10 -years horizon. The predicted dynamics of phytoplankton biomass is well correlated with the evolution of $\mathrm{P}$ availability in the water column.

Briefly, the reduction of $P$ external load into Lake Verde as put in perspective by scenario PORAL may not be sufficient to improve water quality to a mesotrophic state. Considering the economical difficulties in the implementation of the nutrients load reduction program, a concomitant reduction of internal loading (scenario sediments) would be advisable.

\section{Conclusions}

A mathematical model of Lake Verde was developed to make prospective scenarios of water quality and ecological status. The present study has shown how a calibrated mathematical model can be used to support the decisionmaking processes in aquatic restoration programmes. The following conclusions can be drawn:

- The water quality tends to deteriorate unless a strong policy of environmental protection is adopted: annual average values of $34 \mu \mathrm{g} / \mathrm{L}$ total $\mathrm{P}$ and $2.0 \mathrm{mg} / \mathrm{L}$ of phytoplankton biomass can be reached in a 10 -years horizon;

- A reduction of $P$ load into the lake to half of the actual value will improve water quality: an average concentration of total P of $26 \mu \mathrm{g} / \mathrm{L}$ and phytoplankton biomass of $1.4 \mathrm{mg} / \mathrm{L}$ could be reached in a 10-years horizon;

- The reduction of both internal P loads from sediments and external $P$ load into the lake will lead to significant improvements in water quality.

Finally, it is recommended that the present mathematical model is used to integrate the results of future water quality monitoring programmes and to assess the efficiency of the current Lake Verde watershed management plan.

\section{Acknowledgements}

The authors are indebted and grateful to the Regional Department of Water Resources and Land Planning and staff, namely José Gouveia, Margarida Medeiros and Andrea Malcata, and recognize the strong encouragement of Ana Paula Marques, head of the Regional Secretary of Environment and Sea. Gilberto Martins acknowledges Grant SFRH/BD/25639/2005 from the Science and Technology Foundation. 


\section{References}

Antenucci, J.P., Alexander, R., Romero, J.R., Imberger, J., 2003. Management strategies for a eutrophic water supply reservoir - San Roque, Argentina. Water Sci. Technol. 47, 149-155.

A.P.H.A., A.W.W.A., W.P.C.F., 1998. Standard Methods for the Examination of Water and Wastewater, 20th ed. American Public Health Association, Washington, DC, USA.

Burger, D.F., Hamilton, D.P., Pilditch, C.A., 2007. Modelling the relative importance of internal and external nutrient loads on water column nutrient concentrations and phytoplankton biomass in a shallow polymictic lake. Ecol. Model. doi:10.1016/j.ecolmodel.2007.09.028.

Cruz, J.V., Antunes, P., Amaral, C., França, Z., Nunes, J.C., 2006. Volcanic lakes of the Azores archipelago (Portugal): geological setting and geochemical characterization. J. Volcanol. Geotherm. Res. 156, 135 157.

Frisk, T., Bilaletdin, Ä., Kaipainen, H., Malve, O., Möls, M., 1999. Modelling phytoplankton dynamics of the eutrophic Lake Võrtsjärv, Estonia. Hydrobiologia 414, 59-68.

Gonsiorczyk, T., Casper, P., Koschel, R., 1998. Phosphorus-binding forms in the sediment of an oligotrophic and an eutrophic hardwater lake of the Baltic Lake District (Germany). Water Sci. Technol. 37, 51-58.

Gurkan, Z., Zhang, J., Jørgensen, S.E., 2006. Development of a structurally dynamic model for forecasting the effects of restoration of Lake Fure, Denmark. Ecol. Model. 197, 89-102.

Hillebrand, H., Dürselen, C.D., Kirschtel, D., Zohary, T., Pollingher, U., 1999. Biovolume calculation for pelagic and benthic microalgae. J. Phycol. 35, 403-424.

Jørgensen, S.E., Ray, S., Berec, L., Straskraba, M., 2002. Improved calibration of a eutrophication model by use of the size variation due to succession. Ecol. Model. 153, 269-277.

Jørgensen, S.E., Tsuno, H., Hidaka, T., Mahler, H., Santiago V., 2003. PAMOLARE I Training Package, Planning and Management of Lakes and Reservoirs: Models for Eutrophication Management. UNEPDTIEIETC and ILEC, 1091 Oroshimo-cho, Kusatsu, Shiga 525-0001, Japan.

Kim, L.H., Choi, E., Stenstrom, M.K., 2003. Sediment characteristics, phosphorus types and phosphorus release rates between river and lake sediments. Chemosphere 50, 53-61.

Lund, J., Kipling, C., Le Cren, E., 1958. The inverted microscope method of estimating algal numbers and the statistical basis of estimations by counting. Hydrobiologia 11, 143-170.

Medeiros, M.C., Gonçalves, V., Pacheco, D.M., Brito, A.G., Coutinho, R., Santos, M.C.R., Santana, F., 2004. In continuum monotorization of the Lake Sete Cidades (Monitorização in continuum da Lagoa das Sete Cidades). In: Eighth National Conference on Environment ("Actas da 8. ${ }^{\text {a }}$ Conferência Nacional do Ambiente"), Lisbon.
Mukhopadhyay, B., Bhattacharyya, R., 2006. Modelling phytoplankton allelopathy in a nutrient-plankton model with spatial heterogeneity. Ecol. Model. 198, 163-173.

Nogueira, R., Elenter, D., Brito, A.G., Melo, L.F., Wagner, M., Morgenroth, E., 2005. Evaluating heterotrophic growth in a nitrifying biofilm reactor using fluorescence in situ hybridization and mathematical modelling. Water Sci. Technol. 52, 135-145.

Omlin, M., Reichert, P., Forster, R., 2001a. Biogeochemical model of Lake Zürich: model equations and results. Ecol. Model. 141, 77-103.

Omlin, M., Brun, R., Reichert, P., 2001b. Biogeochemical model of Lake Zürich: sensitivity, identifiability and uncertainty analysis. Ecol. Model. 141, 105-123.

Psenner, R., Pucsko, R., 1988. Phosphorus fractionation: advantages and limits of the method for the study of sediment $\mathrm{P}$ origins and interactions. Arch. Hydrobiol. Beih 30, 43-59.

Reichert, P., 1994. AQUASIM - a tool for simulation and data analysis of aquatic systems. Water Sci. Technol. 30, 21-30.

Reichert, P., 1998. AQUASIM 2.0 - User Manual, Swiss Federal Institute for Environmental Science and Technology (EAWAG), $\mathrm{CH}-8600$ Dübendorf, Switzerland.

Ribeiro, D.C., Martins, G., Nogueira, R., Cruz, J.V., Brito, A.G., 2008. Phosphorus fractionation in volcanic lake sediments (Azores Portugal). Chemosphere 70, 1256-1263.

Romero-Gonzalez, M.E., Zambrano, E., Mesa, J., Medina, H.L., 2001 Fractional phosphate composition in sediments from a tropical river (Catatumbo River, Venezuela). Hydrobiologia 450, 47-55.

Santos, M.C.R. Pacheco, D.M. Santana, F.P., Muelle, H., 2004 Cyanobacteria Blooms in Sete Cidades Lakes (S. Miguel Island Azores). In: 16th Symposium on International Association Cyanophyte Research - Luxemburg, 30th August-3rd September.

Utermöhl, H., 1958. Zur Vervollkommnung der quantitativen Phytoplankton-Methodik. Mitt. int Verein. Limnol. 9, 1-38.

Vera, L., Martel, G., Gutierrez, J., Márquez, M., Abreu Acosta, N., Salas, J.J., Sardón, N., Herrera Melián, J.A., Aguilar Bujalance, M.E., Rexachs, J.A., Brito, A.G., Nogueira, R., Ribeiro, D.C., Martins, G., Cunha, J., 2006. "Sustainable Management of Wastewater in Rural Zones: DEPURANAT Project (Gestión sostenible del agua residual en entornes rurales: proyecto DEPURANAT)", first ed. [S.I.], cap 3, Technological Institute of the Canaries (Instituto Tecnológico de Canárias), pp. 111-153. ISBN 84-690-2232-6.

Wang, S., Jin, X., Zhao, H., Wu, F., 2006. Phosphorus fractions and its release in the sediments from the shallow lakes in the middle and lower reaches of Yangtze River area in China. Colloids Surf. A: Physicochem. Eng. Aspects 273, 109-116.

Zhou, Q., Gibson, C.E., Zhu, Y., 2001. Evaluation of phosphorus bioavailability in sediments of three contrasting lakes in China and the UK. Chemosphere 42, 221-225. 